\title{
CAECIDOTEA INSULA, A NEW SPECIES OF SUBTERRANEAN ASELLID FROM LAKE ERIE'S SOUTH BASS ISLAND, OHIO (CRUSTACEA: ISOPODA: ASELLIDAE)
}

\author{
JULIAN J. LEWIS
}

Lewis \& Associates LLC., Cave, Karst \& Groundwater Biological Consulting, 17903 State Road 60, Borden, IN 47106-8608, lewisbioconsult@aol.com

\begin{abstract}
Three species of obligate subterranean asellids were previously known from Ohio, all assigned to the stygia Group of the genus Caecidotea: C. stygia, $C$. filicispeluncae, and $C$. rotunda. Caecidotea insula, n. sp., is described here from two caves on South Bass Island, Ottawa County, Ohio. This island is only $7 \mathrm{~km}$ from the Canadian border. The new species is assigned to an assemblage proposed here as the forbesi Group, which includes the epigean species C. forbesi, C. racovitzai, C. attenuata, and $C$. obtusa. Evidence suggests that $C$. insula evolved as the result of a groundwater invasion by ancestral $C$. forbesi during the late Pleistocene.
\end{abstract}

\section{INTRODUCTION}

Three species of obligate subterranean asellid isopods were previously known from Ohio, all associated with karst habitats along the southern edge of the state (Fig. 1). Each are members of the stygia Group of the genus Caecidotea (Steeves, 1963; Lewis, 1988) containing C. stygia, C. filicispeluncae, and C. rotunda. Caecidotea stygia is one of the most widespread subterranean isopods in the eastern United States with a range extending from southern Indiana through Kentucky into northern Tennessee and west through southern Illinois to east-central Missouri. It was redescribed from specimens on the eastern edge of its range collected in southwestern Ohio (Bowman and Beckett, 1978). Caecidotea filicispeluncae was described from Fern Cave, Adams County (Bowman and Hobbs, 1983) and is endemic to that site. Caecidotea rotunda was described from collections in southern Ohio and southeastern Indiana (Bowman and Lewis, 1984).

The discovery of an obligate subterranean isopod in caves on South Bass Island, only $7 \mathrm{~km}$ from the Canadian border, in Lake Erie is remarkable for its occurrence there. Peck (1998) listed only four obligate subterranean species in Canada, and none were known from east of the Rocky Mountains. The potential for discovery of obligate subterranean organisms in eastern Canada should not be dismissed, especially in hyporheic and epikarstic habitats. As a case in point, the new isopod was taken from a pool collecting water dripping in from the epikarst.

\section{Family Asellidae}

Caecidotea Packard, 1871

forbesi Group (new species group)

Diagnosis of male-Eyes and pigmentation present or absent. Palmar margin of pereopod 1 propodus with median triangular process. Pleopod 1 subequal or shorter than pleopod 2, exopod distal margin with short, non-plumose setae. Pleopod 2, exopod, distal article ovate, large in relation to and longer than endopod, widest along midlength, with numerous elongate plumose setae along margins; endopodite tip with broadly rounded, sclerotized caudal process, cannula relatively short, blunt, extending parallel to axis of endopod, mesial process present.

The following species are assigned to the forbesi Group: Caecidotea forbesi, C. racovitzai, C. obtusa, C. attenuata, and $C$. insula.

Caecidotea insula, new species

Figures 2-3

Material examined - OHIO: Ottawa County, drip pool in Kindt's Cave I, town of Put-in-Bay, near center of southern half of South Bass Island, collected Wittenberg University Speleological Society, 5 August 2007, holotype male; drip pool in Kindt's Cave II, Wittenberg University Speleological Society, 5 August 2007, one paratype male. The specimens have been deposited in the collection of the National Museum of Natural History, Smithsonian Institution.

Description-Eyeless, unpigmented, longest $9.3 \mathrm{~mm}$, approximately $4.2 \times$ as long as wide. Margins of head, pereonites, and pleotelson densely setose. Head approximately $1.9 \times$ as wide as long, post-mandibular lobes modestly produced. Pleotelson slightly longer than wide, caudomedial lobe distinct.

Antenna 1 flagellum with 10 articles, distal 4 articles with esthetes. Antenna 2 last article of peduncle approximately $1.5 \times$ length of preceding article, flagellum with 61 articles. Mouthparts per the diagnosis of the genus (Lewis 2009).

Pereopod 1 propodus subtriangular, approximately $1.4 \times$ as long as wide, palmar margin with stout proximal seta, high triangular median process, lower rounded distal process. Dactylus slightly longer than palmar margin of propodus.

Pleopod 1 slightly shorter than pleopod 2, protopod approximately $0.7 \times$ length of exopod, 2 retinacula; exopod approximately $1.7 \times$ as long as wide, ovate, mesial and 


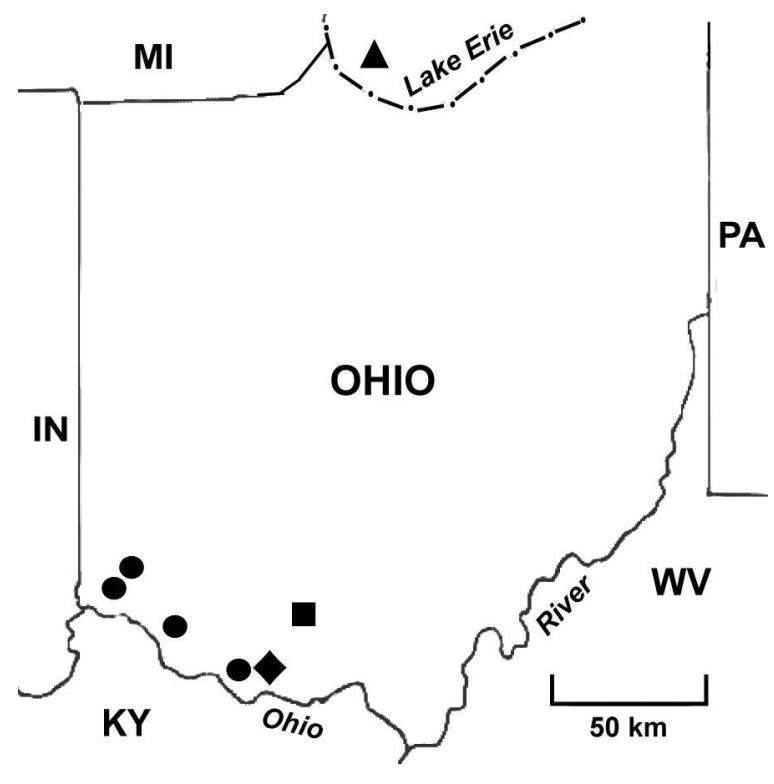

Figure 1. Approximate locations of subterranean asellid isopods in Ohio: triangle, Caecidotea insula; circles, $C$. stygia; diamond, C. filicispelunca; square, C. rotunda.

lateral margins broadly rounded, sparse non-plumose setae on distal margin.

Pleopod 2, protopod subquadrate, about $1.35 \times$ as long as wide; exopod about $1.6 \times$ length of endopod, proximal article with 2 small lateral setae, distal article slightly longer than endopod, ovate, with 14 plumose setae along margins increasing in size at apex; endopod with broadly rounded basal apophysis, tip with 4 processes in anterior view: (1) cannula broad, distally flat, (2) mesial process prominent, distally hooked mesiad, with endopodial groove barely visible at base; (3) lateral process low, broad, partially obscured by mesial process, extending slightly beyond margin of endopod; (4) caudal process prominent, broadly rounded, sclerotized.

Pleopod 3 exopod, proximal to transverse suture about $0.6 \times$ length of distal part; elongate plumose setae along distal and lateral margins, tapering in length to suture. Pleopod 4 exopod with 2 false sutures, proximolateral margin with 2 setae and numerous setules. Pleopod 5 exopod with 3 proximolateral setae. Uropods detached and missing from vial.

Etymology-The name is from the Latin noun insula $=$ island, referring to the location of the type-locality on South Bass Island.

Vernacular name-The suggested common name is the Kindt's Cave isopod, referring to the Kindt family in honor of their stewardship of the cave.

Range-Caecidotea insula is known from two caves on South Bass Island, Ohio, in southwestern Lake Erie. The Kindt's Caves are clustered a little southwest of the center of the southern half of the island, within the village of Putin-Bay. Verber and Stansberry (1953) provided a map with the locations of twenty-eight caves on the island, including three Kindt's Caves. The potential range encompasses South Bass Island, which is approximately $6 \mathrm{~km}$ long by $2.4 \mathrm{~km}$ wide, with a narrow isthmus separating the smaller northern section from the larger southern part of the island.

Habitat - In contrast to other caves of the eastern U.S. formed by dissolution of carbonate bedrock, many caves on South Bass Island are the product of collapse of the Putin-Bay and Tymochtee dolomites into voids created by dissolution of underlying gypsum domes (Verber and Stansberry, 1953). This produced short, crescent-shaped caves around the edge of the collapsed domes. The three Kindt's Caves are clustered around such a collapsed dome. Kindt's Cave I has been surveyed at 164 meters in length, while Kindt's Cave II is 144.4 meters long. The entrance to Kindt's Cave III has been filled for several decades and little is known about it (Athy, pers. comm., 2010). The specimens of $C$. insula were collected from shallow pools of drip water originating in the epikarst (Hobbs, pers. comm., 2010). The isopods have also been seen in the deeper, base level pool in the lowest part of the cave (Athy, pers. comm., 2010). The level of these pools is equivalent to the top of the local water table, which fluctuates with the level of Lake Erie (Verber and Stansberry, 1953).

Relationships - The morphology of Caecidotea insula most closely resembles C. forbesi (Williams, 1970), an epigean species widespread in the eastern U.S. and southeastern Canada. Although troglomorphism does not in itself imply speciation, the two species are easily separated by the absence of eyes and pigmentation in $C$. insula. Caecidotea forbesi has large, distinct eyes and pigmentation typical of a surface-dwelling species. The habitus of $C$. insula is not particularly vermiform as compared to other subterranean Caecidotea, but the male gnathopod propodus is more attenuate than that of $C$. forbesi. In $C$. insula the propodus is subtriangular and about $1.4 \times$ as long as wide. In $C$. forbesi, the propodus is subtrapezoidal and slightly wider than long (Williams, 1970). In both species the palm of the propodus has a large median process and a low distal process. The male first pleopods are essentially identical in appearance. The resemblance of the male second pleopod of the two species is strong, but differs in details of the tip structures of the endopod. In $C$. forbesi, the endopodial groove is prominent in anterior aspect, but it is barely visible in $C$. insula, where it seems to run behind the decurved mesial process. A subcaudal lateral process is present in $C$. insula, but undifferentiated in $C$. forbesi.

The morphological similarity of $C$. insula to $C$. forbesi suggests a close relationship with the group of four epigean species proposed here as the forbesi Group (C. forbesi, C. racovitzai, $C$. obtusa, $C$. attenuata) indicated by the phylogeny of Williams (1970). This is the only described subterranean asellid in North America belonging to a group of species that is otherwise entirely epigean. 


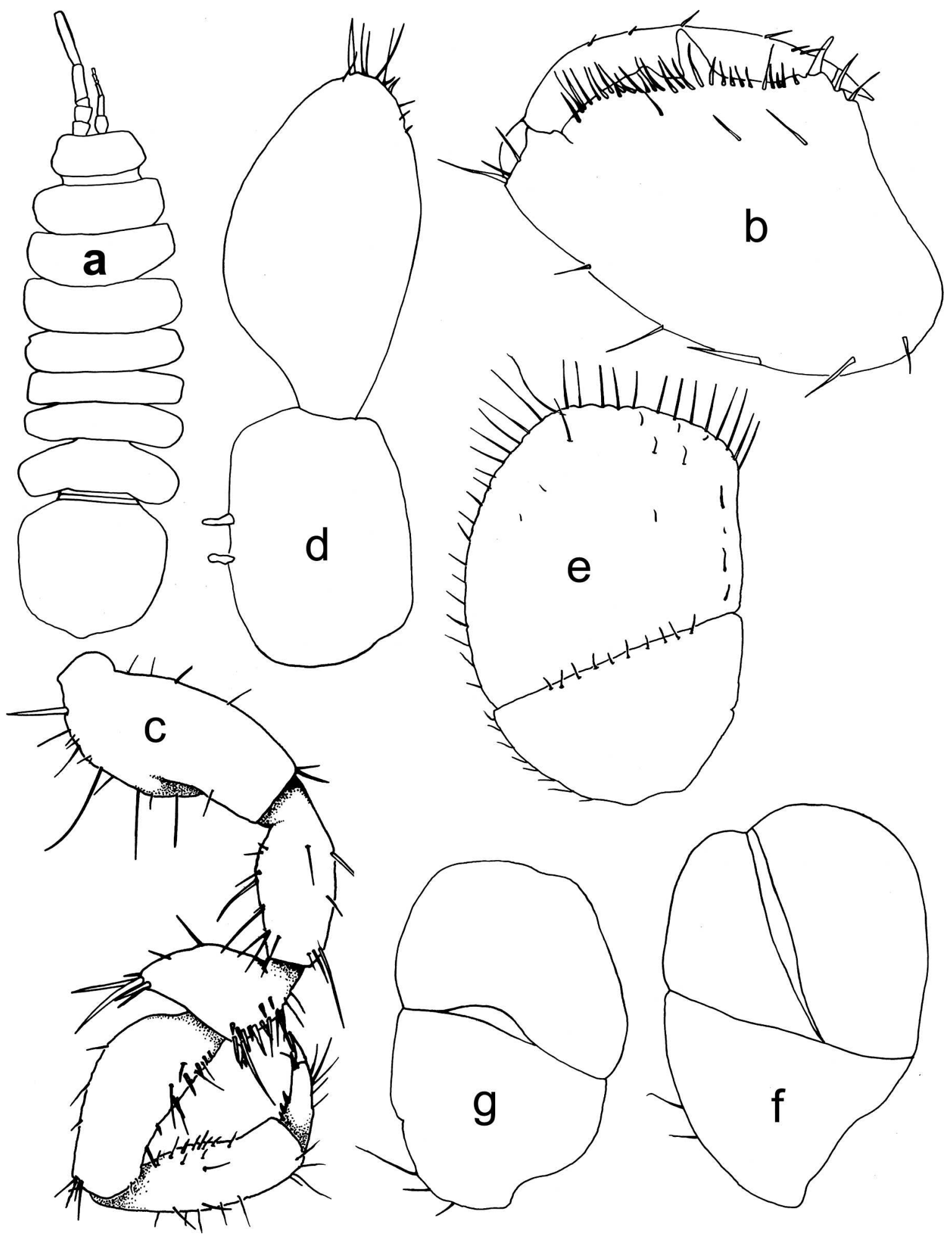

Figure 2. Caecidotea insula, new species: (a) habitus, (b) pereopod 1 propodus, (c) pereopod 4, (d) pleopod 1, (e) pleopod 3 exopod, (f) pleopod 4 exopod, (g) pleopod 5 exopod.

Evolution-The area where $C$. insula occurs was covered by the Wisconsinan glacier until about 14,000 years before present (Forsyth, 1988). As the glacier receded, new aquatic habitats presented opportunities for the forbesi-insula 66• Journal of Cave and Karst Studies, April 2013 ancestral species. Williams (1970) reported that $C$. forbesi does not occur in Lake Erie, so as the relatively deep water lake formed in the post-glacial era, that species must have moved to other areas. Today, $C$. forbesi is one of the most 


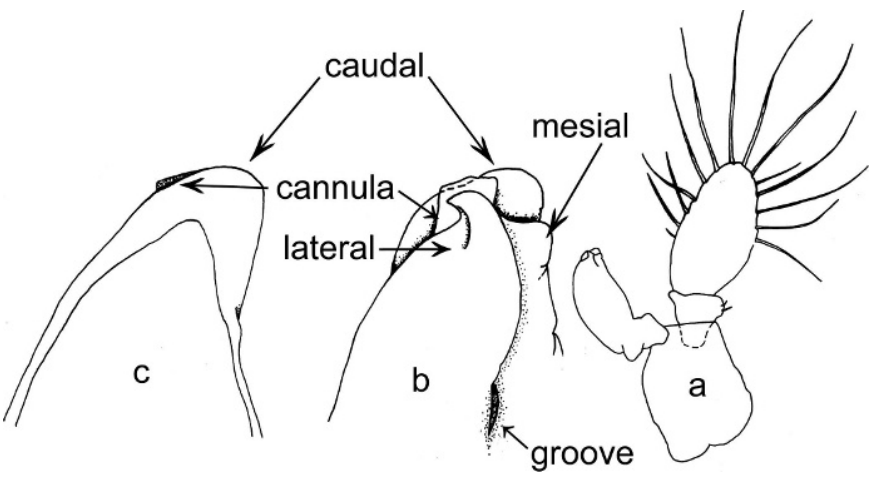

Figure 3. Caecidotea insula, new species: (a) pleopod 2, (b) same, endopodite tip, anterior aspect, (c) same, posterior aspect.

common aquatic isopods in eastern North America, including many sites peripheral to Lake Erie. A population stranded on South Bass Island was geographically, and thus genetically, isolated. It is not difficult to envision an isopod like C. forbesi, a frequent inhabitant of temporary pools, following water downward as its habitat dried, and thus invading and colonizing groundwater. Whatever the cause, the result was the presence of the species recognized here at C. insula on South Bass Island.

Steeves (1969) noted another subterranean species only slightly changed morphologically from its epigean relative. That species was designated as undescribed species D by Steeves, known only from Lawson's Cave, in an isolated valley called Burkes Garden, Tazewell County,Virginia. I have examined collections from Lawson's Cave and found the isopods to be eyeless and unpigmented, but otherwise indistinguishable from the epigean $C$. racovitzai (Lewis, 2009). Likewise, specimens from some caves in central Florida are troglomorphic, i.e., eyeless and unpigmented, but otherwise morphologically identical to $C$. racovitzai.

As the asellid fauna of eastern North America becomes better understood, trends in the evolution of the group are becoming evident. A recurrent theme that is emerging among the species of the forbesi Group is their penchant for recent groundwater invasions. Until the discovery of the Caecidotea in Kindt's Caves, none of the taxa were known from demonstrably geographically isolated sites.
The presence of $C$. insula on an island in Lake Erie is reasonable evidence of genetic isolation.

\section{ACKNOWLEDGEMENTS}

I thank Dr. Horton H. Hobbs III and Erin Athy for sending me the interesting specimens of the new species and providing unpublished information on their collection and the caves on South Bass Island. The preparation of this paper was supported by funds from the Cleveland Grotto Science Fund, Lake Erie Islands Chapter of the Black Swamp Conservancy, Dayton Underground Grotto, and Wittenberg University Speleological Society.

\section{REFERENCES}

Bowman, T.E., and Beckett, D.C., 1978, A redescription of the troglobitic isopod, Caecidotea stygia, from the environs of Cincinnati, Ohio (Crustacea: Isopoda: Asellidae): Proceedings of the Biological Society of Washington, v. 91, no. 1, p. 294-302.

Bowman, T.E., and Hobbs, III, H.H., 1983, Caecidotea filicispeluncae, a new troglobitic asellid isopod from Ohio: Proceedings of the Biological Society of Washington, v. 96, no. 4, p. 693-697.

Bowman, T.E., and Lewis, J.J., 1984, Caecidotea rotunda, a new troglobitic asellid from Indiana and Ohio (Crustacea: Isopoda: Asellidae): Proceedings of the Biological Society of Washington, v. 97, no. 2, p. 425-431.

Forsyth, J.L., 1988, The geologic setting of the Erie islands, in Downhower, J.F., ed., The Biography of the Island Region of Western Lake Erie, Columbus, Ohio State University Press, p. 13-23.

Lewis, J.J., 1988, The systematics, zoogeography and life history of the troglobitic isopods of the Interior Plateaus of the eastern United States: $\mathrm{Ph} . \mathrm{D}$. dissertation, University of Louisville, Louisville, Kentucky, $281 \mathrm{p}$.

Lewis, J.J., 2009, Three new species of Caecidotea, with a synopsis of the asellids of Virginia (Crustacea: Isopoda: Asellidae), in Roble, S.M., and Mitchell, J.C., eds., A Lifetime of Contributions to Myriapodology and the Natural History of Virginia: A Festschrift in Honor of Richard L. Hoffman's $80^{\text {th }}$ Birthday: Martinsville, Virginia Museum of Natural History Special Publication, no. 16, p. 245-259.

Peck, S.B., 1998, A summary of diversity and distribution of the obligate cave-inhabiting faunas of the United States and Canada: Journal of Cave and Karst Studies, v. 60, no. 1, p. 18-26.

Steeves, III, H.S., 1963, The troglobitic asellids of the United States: the Stygius Group: American Midland Naturalist, v. 69, no. 2, p. $470-481$

Steeves, III, H.S., 1969, The origin and affinities of the troglobitic asellids of the southern Appalachians, in Holt, P.C., ed., The Distributional History of the Biota of the Southern Appalachians, Part I, Invertebrates, Blacksburg, Virginia Polytechnic Institute and State University, Research Division Monograph I, p. 51-65.

Verber, J.L., and Stansberry, D.H., 1953, Caves in the Lake Erie Islands: Ohio Journal of Science, v. 53, no. 6, p. 358-362.

Williams, W.D., 1970, A revision of North American epigean species of Asellus (Crustacea: Isopoda), Washington, Smithsonian Contributions to Zoology 49, 80 p. 